\title{
Morphometric Study of Bangalore Metropolitan City, Karnataka, India
}

\author{
Shivanna S. ${ }^{1}$, Vyshnavi D. R. ${ }^{2}$ and Sriram Mustapure ${ }^{3}$ \\ ${ }^{1,2}$ Dept of Civil Engineering, \\ Sir M Visvesvaraya Institute of Technology, Bangalore - 563157 \\ ${ }^{3}$ Dept. of Civil Engineering (Water Resources Section), \\ UVCE, Bangalore -560 056
}

\begin{abstract}
Bangalore in earlier days was very well known as the City of Lakes. Kempegowda, the founder of Bangalore, who had broad vision, established several tanks and lakes to impound runoff water, so that the water could be utilized for better purposes and also enhanced the beauty of the city. According to several reports there were around 280 tanks to meet the water demand. But today the figure has declined to about 81 , of which 34 are recognized as live lakes. This number denote a reduction of water bodies as high as $35 \%$, while in terms of water spread area it shows a decrease of $8.6 \%$ In this context a systematic morphometric analysis has been carried out and the results are presented
\end{abstract}

Keywords: Morphometric analysis, Urbanization, Rainfall, Climate, Drainage, DEM.

\section{Introduction}

in Bangalore dates back to the later part of the 16th century, when the founder of Bangalore, Kempegowda built the Ulsoor tank covering an area of 125 acres. Most of the lakes and tanks were manmade for the purpose of drinking water, irrigation and fishing needs and they have also favourably influenced the micro-climate of the city. The lake waters have also served as "Dhobi Ghats" or places where washer-men have traditionally used them as a means of livelihood for washing clothes and drying them. The lakes have also served to replenish ground water resources in the vicinity, which are tapped through wells for drinking water. The first instance of contamination of Ulsoor tank by sewage was reported way back in 1883 after which the use of lake water for the purpose of public consumption was prohibited. Records show that till 1960 there were 280 water bodies in Bangalore city. Today the figures have declined to about 81 of which, 34 are recognized as live lakes. These figures denote a reduction of water bodies as high as $35 \%$, while in terms of water spread area it shows a decrease of $8.6 \%-$ In the 1970 s the scheme to pump water from the Cauvery River from 100 kilometres away was begun. The water needed to be raised up by 500 meters. The water demand in 2001 was 750 million litres per day. Bangalore is also the technological capital of India. Hence, it attracts people from various parts of the country. This has caused many problems like increase of population and water demand.

Morphometric analysis has been carried out to understand the hydro-geological conditions of the watershed. Remote sensing and Geographic information system were used for the assessment of linear, aerial and relief of the study area (Horton 1932, 1945; Langbein 1947; Miller 1953; Narayanaswamy et al. 2014, 2017; Shivanna et al. 2017, 2018; Shivanna and Vyshnavi 2019; Schumm 1956, Strahler 1952, 1957). Quantitative morphometric analysis of any area reflects its hydrological behavior and is therefore useful in evaluating hydro-geological responses of the area. Bangalore metropolitan city has been studied to quantify the morphometric characteristics that will reveal its geographic behavior. The study area exhibits the dendritic drainage pattern that indicated moderate to nil flood intensity. In order to know and asses the quantity of water available for utilization a systematic hydro-geological study is essential. In this 
contest a systematic morphological study has been carried out and preliminary results are presented.

\section{Study area}

Bangalore Metropolitan city is a part of Arkavathi and Pennar river basins. The study area exhibits the dendritic pattern of drainage network.

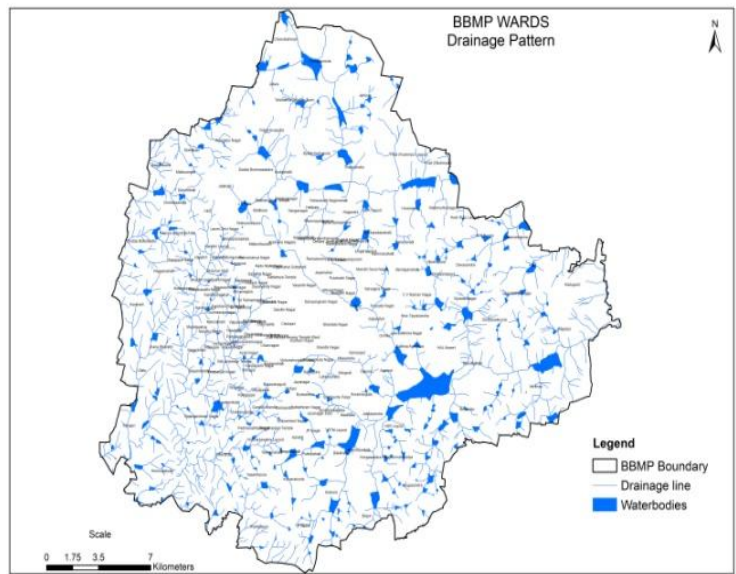

Fig. 1:Drainage map of the study area.

By using the Survey of India toposheets we have prepared the Geological, Drainage, geomorphic, slope and rainfall pattern maps have been prepared by using Arc GIS software for the present study. (Figures 1, 2, 3, 4, 5)

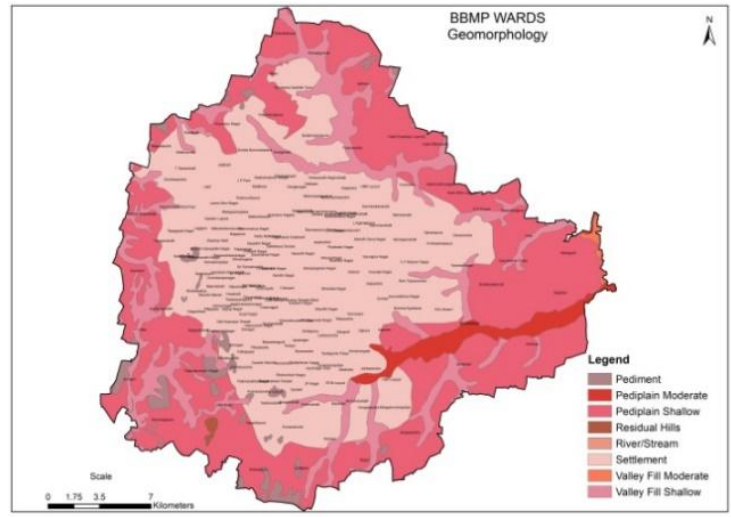

Fig.2: Geomorphic map of the study area.

Geologically the city of Bengaluru is largely laid on gneisses and granites forming part of the Peninsular gneissic complex. These comprise coarse augen, gneisses, migmatites, dioritic to granodioritic gneisses and grey biotite granite. The eastern part of Bengaluru comprises predominantly banded

\section{ISSN 2455-6378}

gneisses. They become more intricately folded further westwards N-S trending Hebbal Basavanagudi -Buglerock-Banashankari granite ridge. The dark biotite gneisses contain enclaves of amphibolites, chlorite-tremolite schists and quartzites referable to the Sargur complex. A forecited prominent $\mathrm{N}-\mathrm{S}$ trending intrusive granite body along the Hebbal - Basavanagudi-Banashankari axis forming topographically high zone is mainly a grey granite body.

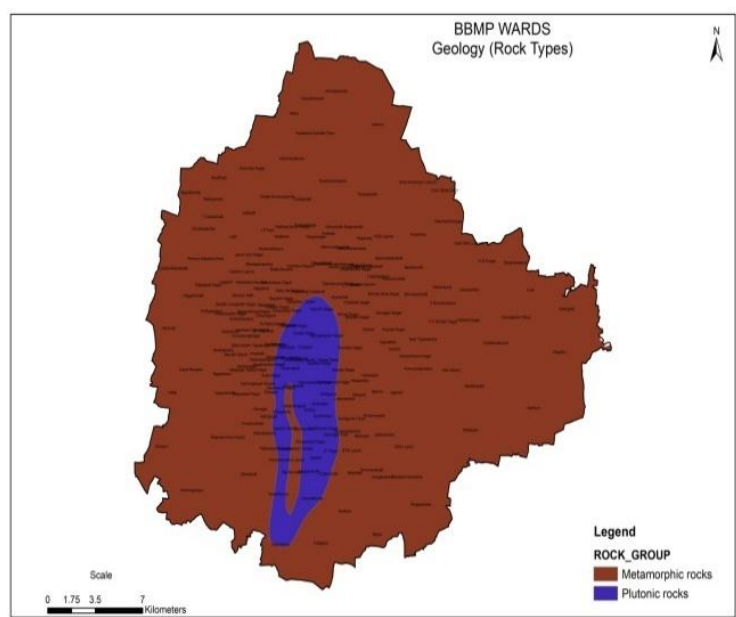

Fig.3:Geological map of the study area.

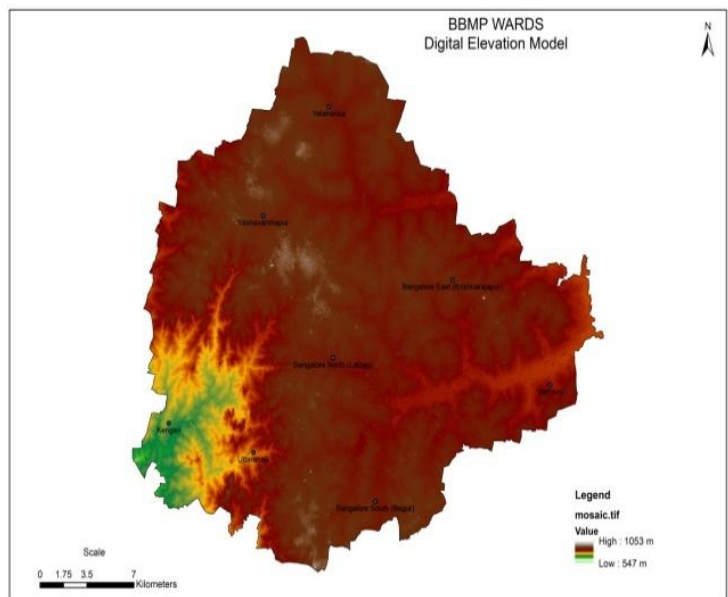

Fig.4: DEM (Slope) map of the study area.

Gneisses have undergone various stages of weathering. This has produced clayey soil which form low lying areas. There is local capping of laterite along higher grounds. Soil cover is of variable thickness. It is variously lateritic in nature. Red soil is also commonly seen. The weathered zones within the peninsular gneissic complex are the main permeable zones and promote movement of 
water and development of shallow aquifers. Areas where clays predominant have a poor permeability. The dug wells were mainly based on shallow aquifers, where the base of the weathered rocks are highly jointed and fractured they have facilitated further percolation and development of deeper aquifers. Tree cover and ground vegetation have also played important roles in the ground water recharge. Bangalore is situated at the altitude of over 915 meter above sea level. Lying to the east of the major north-south (N-S) trending Tumkur - Closet Granite Hill range, the city is located on the water shed of two river basins, the Arkavathi to the west and south, and the Pennar Basin to the east. The topography of the Bangalore is also characterized by the welldefined radiating valleys and gradual fault towards the wide belt of flat land. The three principle valleys are known as Vrishabavathi, Koramangala and Chellagatta. The naturally undulating terrain of hills and valleys, lends itself to the development of lakes that can capture and store rain water. A series of tanks of having varying sizes are also developed. The streams between ridges and valleys were dammed at suitable location creating the cascade of reservoirs in each of the three valley systems serving as a source of water for the inhabitants. The gentle topography has also well for potential groundwater development. But the unplanned urbanization has caused the environmental degradation, disruption of natural drainage and robbed the area of its natural topographic advantages for storing water. This is also responsible for flooded during spells of heavy rain as natural drainages have been blocked. The mean annual rainfall is $859 \mathrm{~mm}$ with the principle rainy season lasting from June to September (Southwest Monsoon) and the secondary rains takes place in the month of November and December regularly (North-east Monsoon).

\section{Materials and Methods}

A detailed study of the rainfall over the catchment is an essential aspect of groundwater study in the present investigation. Rainfall is the main source of both surface and groundwater. Its seasonal distribution will give an idea to know the local recharge by rain or precipitation and would influence the groundwater body. For the present study data from all rain gauge stations have been collected and analysed. The rainfall plays an important role in controlling the occurrence subsurface water in different levels of the earth crust.

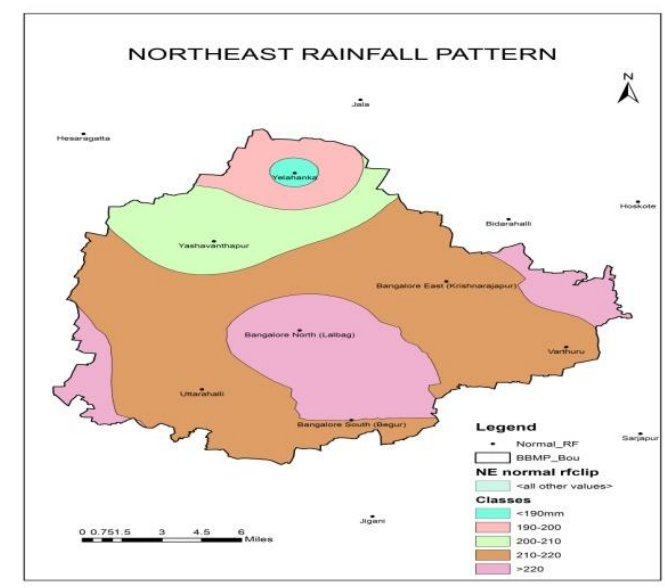

Fig.5: Rainfall pattern during Northeast Monsoon in the study area.

There is a variation in the normal annualrainfall in the study area. From the figure 6 . it is seen that there is slightly lesser rain fall in the northern part (less than $800 \mathrm{~mm}$ ) and medium rainfall in the northeastern part (800 to $900 \mathrm{~mm}$ ) and slightly high rain fall in the middle ofBangalore (900 to $965 \mathrm{~mm}$ ). But there is a lot of variation during the northeast monsoon in the entire Bangalore city (Figore 5)

\section{Rainfall}

The average annual rainfall of the study area is 909.2 $\mathrm{mm}$. The lowest rainfall is less than $800 \mathrm{~mm}$ (Figure $6)$.

\section{Water Problems}

Bangalore was a well-planned city during its initial days, and 4 towers built by Kempegowda marked the borders of the city. As the city grew, it crossed the borders and became messy like any other metropolitan city of India. As the population increased, there was a huge need for accommodation of people. To provide accommodation, many lakes were destroyed and many buildings were built on the site of the lakes. Many trees were cut in the name of development. The lakes are maintained in a bad condition. Bellandur Lake has become famous for the toxic foam, which is affecting the health of many people in the surrounding area. 


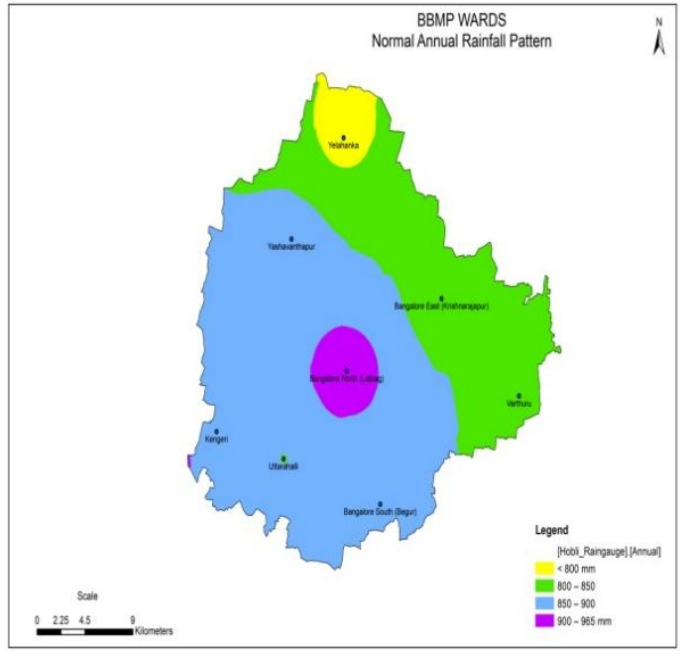

Fig.6: Rainfall pattern in the study area

\section{Urbanization}

Urban population in Asia rockets from 678 million in 1980 to 1.85 billion in, with China and India being the leading countries. Several cities in India have dramatic rates of urban expansion, such as Bombay, Calcutta, Delhi and Bangalore (Hove 2006). Among them, Bangalore grows the fastest in Asia and its urban area began to form in 1986. Bangalore is the capital of Karnataka. Because of its burgeoning IT industries, Bangalore is nicknamed India's "Silicon City." Also, it is an international air hub. Bangalore is now known as Bruhat Bangalore Mahanagara Palike (BBMP) the biggest urban area with an extent of 850 sq. km. By 2012, Bangalore will join Mumbai, Delhi and Kolkata as a mega city in India.

\section{Results and Discussion}

In the present investigation several maps have been prepared to know the groundwater conditions and demand for water to the existing population. The geo-morphological study reveals that most of the rocks underlined in the study area were highly fractured and jointed. But due to unplanned developmental activities all these structures like joints, fractures anfissure have been completely covered by the concrete buildings, which in turn reduces recharging mechanism of the groundwater. All the three (Challagatta, Vrishabavathi and Hebbal) valleys have been completely blocked and natural drainage pattern is also changed to certain extent, which in turn leads to flooding during southwest
ISSN 2455-6378

monsoon. The urban expansion around Bangalore has put enormous pressure on water supply, which could present a huge issue as Bangalore relies heavily on ground water. Ground water contributes to fifty percent of the urban water requirements and eighty percent of the drinking water in rural areas. Due to increasing water consumption in Bangalore, the level of ground water keeps declining regularly. Recent satellite images show that only 34 lakes are visible. Due to rural migration, lack of infrastructure becomes a major impediment to the urbanization in Bangalore. City administration is facing the challenging task of providing necessary infrastructure for related economic activities, trade, and commerce and housing facilities. Frequent flooding and micro-climatic change in the city leads to desirable impact on the diversity of flora and fauna as well as decrease in the number of migratory birds.

\section{Conclusions}

Remote sensing and GIS tools have made more easier for calculating various parameters of the morphometric analysis. Based on the present investigation the Bangalore city is exhibiting dendritic pattern of drainage system. This drainage pattern obeys the Hortons law (Horton 1945) in relation to the linear and aerial aspects in the present study. The study area is hard rock terrain with semiarid climatic condition. The drainage pattern of the study area is mainly controlled by lithology and structures. The drainage of the study area is divided by a ridge existing in the central part of the city. All the results of the morphometric analysis of the study can be used for planning of flood management, soil erosion assessment, water resources management and sustainable development in the Bangalore Metropolitan city.

\section{Acknowledgments}

Dr. Shivanna S and Mrs. Vyshnavi D R thank the Management of Sri Krishnadevaraya Educational Trust, Bangalore for the support and encouragement. Also thank Ms. Rajini, Ms. Deepthi, and Ms. Shrishti, 2016 Batch Civil Engineering Students of Sir M Visvesvaraya Institute of Technology, Bangalore for their help in the field study. 


\section{References}

[1] Horton R.E.:Drainage Basin Characteristics., Trans American. Geophysical. Union, Vol. 13, pp.350-361.(1932)

[2] Horton R.E.: Erosional Development of Streams and their Drainage basin: Hydro-physical Approach to Quantitative Morphology. Geol. Soc. Am. Bull. Vol.56, pp.272-370.(1945)

[3] Langbein W.B.: Topographic Characteristics of Drainage basin., USGS Water Supply Paper., 968C, pp.125-153.(1947)

[4] Miller V.C.: A Quantitative Geomorphic study of drainage basin characteristics in Clinch Mountain area., Technical Report No.3, Department Geology, Columbia University, USA(1953)

[5] Narayanaswamy N.K., Shivanna S., Brahmananda, S.B. and Vajrappa, H.C.:A GIS based Morphometric Analysis and Associated Landuse Study of Dakshina Pinakini River Basin, Chikkaballapur and Bangalore Rural Districts, Karnataka., Journal of Applied Hydrology, Vol.27., No. (1-4)., pp.52-62(2014).

[6] N K Narayana Swamy., H C Vajrappa., Shivanna, S., S B Bramhananda: Remote Sensing and Hydro-Geo-morphological Studies to Evaluate Groundwater Potential Zones of Dakshina Pinakini River Basin, Chikkaballapura and Bangalore Districts, Karnataka. International Journal of Research, Engineering and Technology, Vol. 5., Issue 07., pp. 347351(2016).
[7] Schumm S.A.: Evolution of drainage systems and slopes in Badlands at Perth Ambey, New Jersey, Geol. Soc. Am. Bull. Vol. 67., pp. 597-598,636641, and 645-646.(1956)

[8] Shivanna,S., Anupama, V.S., Vyshnavi, D.R. and H.P. Mahendra Babu : A GIS based Morphometric Analysis and Associated Landuse Study of Hesaraghatta Watershed, Bangalore District, Karnataka., IJRSI, Vol.4., pp.4852.(2017)

[9] S. Shivanna., D. R. Vyshnavi., S. B. Bramhananda and N. K. Narayanaswamy: Land use and Land cover Study of Vrishabhavathi River Basin, Karnataka, Journal of Applied Hydrology, Vol 31., No.1-4., pp.110-118. (2018).

[10] Shivanna $\mathrm{S}$ and Vyshnavi $\mathrm{D}$ R: Geomorphological Study of Yelahanka Watershed, Bangalore Rural District, Karnataka, IndiInternational Journal of Advanced Scientific Research and Management., Vol.4., Issue 8., pp.73-77. (2019)

[11] Strahler A.N.:Hypsometric Analysis of Erosional Topography., Geol. Soc. Am. Bull., Vol.63, pp.1117-1142.(1952)

[12] Strahler A.N.:Quantitative Analysis of Watershed Geomorphology., American. Geophysical. Union.Trans., Vol. 38(6), pp.913920.(1957) 